\title{
Single nucleotide polymorphism analysis in meat-production related genes in broiler chickens
}

\author{
Klaudia Szalai - Károly Tempfli - Erika Lencsés-Varga - Ágnes Bali Papp \\ Széchenyi István University Faculty of Agricultural and Food Sciences, Mosonmagyaróvár, Hungary \\ szalai.klaudia@sze.hu
}

\begin{abstract}
SUMMARY
In broiler chickens, the intensive selection for growth rate, feed efficiency, body composition (breast muscle weight) traits in the last decades was successful. To improve economically important characteristics, it is possible to use molecular markers associated with meat production traits. The aim of this study was to examine genotype polymorphisms in ROSS 308 broilers for thyroid hormone responsive Spot14a, insulinlike growth factor 1 (IGF1), IGF-binding protein 2 (IGFBP2), somatostatin (SST) and prolactin (PRL) genes. A further goal of this investigation was to study the relationship between the polymorphisms and phenotypic characteristics.

In the investigated broiler population, the frequency for CC homozygous genotype was 0.77 in Spot14a (AY568628), AA homozygous genotype was 0.80 in IGF1 (M74176), GG homozygous genotype was 0.85 in IGFBP2 (U15086), DD homozygous genotype was 0.60 in PRL (FJ663023 or FJ434669). Only the AA homozygous genotype was found in SST (X60191). Chickens with AC genotype in Spot14a, and with GG genotype in IGFBP2 had higher body weight $(B W)$ and carcass weight $(C W)$, compared to CC and GT genotypes. However, the differences were not significant $(P>0.05)$. There was significant association $(P<0.05)$ between PRL genotypes and body and carcass weight, where chicken with homozygous DD surpassed individuals with homozygous II genotypes.
\end{abstract}

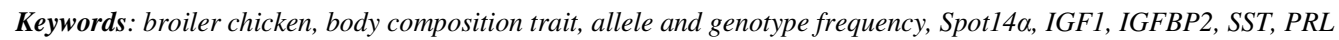

\section{INTRODUCTION}

The intensive application of selection methods in broiler chicken has successfully increased growth rate, feed efficiency, carcass yield, and breast muscle percentage. Allele frequency analyses are often used to identify potential candidate genes and polymorphisms, and are important for the selection of advantageous genotypes. Application of molecular markers associated with meat and egg production is a potential tool to improve production yields.

The thyroid-hormone responsive Spot 14 gene (also known as THRSP) was identified as duplicated polymorphic paralogs in chicken, namely Spot $14 \alpha$ and Spot14ß. Spot14 is implicated as a transcription factor on lipogenic genes promoters, involved in control of lipogenic enzymes (Wang et al. 2004). Furthermore Spot $14 \alpha$ is maintaining a connection between thyroid hormone concentrations and growth (Cao et al. 2007, d'André Hirwa et al. 2010). Expression of Spot $14 \alpha$ mRNA is also regulated by thyroid hormone status (Wang et al. 2004).

The insulin-like growth factor 1 (IGF1) is a candidate gene for growth, body composition, metabolic, fat deposition and skeletal traits in chicken (Zhou et al. 2005). Most of the functions of growth hormone $(G H)$ in chickens are mediated by $I G F$ s (Lei et al. 2005). There is a negative genetic correlation between breast muscle and fat deposition in chicken (Sato et al. 2012).

The IGF-binding protein type 2 (IGFBP2) may play an important role in the modification of the growth supporting effect of circulating IGFI by producing the $I G F B P$ complex in chicken (Kita et al. 2002 ), and by regulating IGF transport to tissues and IGF bioavailability to IGF receptors at cell membrane level (Silha and Murphy 2005). The association of the
$I G F B P 2$ gene with body weights has been proved in Jinghai chickens (Zhao et al. 2015).

The somatostatin (SST) encodes for two biologically active cyclic peptide forms (SST-14 and $S S T-28)$. The SST regulates the secretion of numerous hormones. Despite polymorphisms in SST gene have large effects on growth and body composition in mammals SST is characterized up to now in four chicken populations (Nie et al. 2005). Genotypegrowth associations have not been performed.

Prolactin (PRL) hormone has a diverse spectrum of functions including growth, development, metabolism, reproduction, behaviour, and immune regulation in vertebrates, and plays main roles in several reproductive processes in avian species (Angelier and Chastel 2009). PRL takes part in several biological functions; however, only limited genotypegrowth associations have been reported in chicken (Bhattacharya et al. 2011).

\section{MATERIAL AND METHODS}

Experimental population, sample and data collection at the abattoir

The analyzed hybrids were ROSS 308 (meat-type chicken). Five polymorphisms in growth or egg production-related genes (see below) were selected for genotyping in chicken populations. The experimental animals $(n=40)$ were fattened under identical housing and feeding conditions. Feed was produced by the same plant. Feed and water were given ad libitum. The broilers involved in this investigation were randomly selected. The sex of animals was genetically not determined. Males were selected by means of visual discrimination. The chickens were slaughtered at 35 days of age. Legs of chickens were individually marked. Feathers samples were collected from the individuals for the identification of Spot14 $\alpha$, IGF1, 
IGFBP2, SST, PRL genotypes. Samples were stored at $-20{ }^{\circ} \mathrm{C}$ pending processing.

The body weight $(B W)$ of broilers was measured before slaughtering, and carcass weight $(C W)$ was measured before refrigerating. After refrigerating (2 hours at $\left.4{ }^{\circ} \mathrm{C}\right)$, the breast muscle fillets with $(B M W S)$ and without skin $(B M W)$, the legs with skin and bone $(L W)$ were measured, and their percentage of carcass and body weight were also calculated. Chickens were dissected by the slaughterhouse staff.

\section{Isolation of DNA and PCR-RFLP}

Extraction of DNA from feathers was done with Wizard Genomic DNA Isolation kits (Promega, USA), according to manufacturer's instructions. DNA concentration and purity were determined using a
NanoDrop 2000 spectrophotometer (Thermo Fischer Scientific, USA), both $260 / 280$ and $260 / 230$ ratios of samples exceeded 1.8. The integrity of DNA was controlled by agarose gel electrophoresis.

Polymerase chain reaction (PCR) and restriction fragment length polymorphism (RFLP) techniques with agarose gel electrophoresis were used to identify genotype. With slight amendments the genotyping methods for the A213C locus in Spot $14 \alpha$ by Cao et al. (2007), the A570C locus in IGFI by Zhou et al. (2005), the $24 \mathrm{bp}$ insertion in PRL by Jiang et al. (2005) were applied. Primers were designed and RFLP was constructed for non-synonymous SNPs, the G645T SNP in IGFBP2 and A370G SNP in SST (Table 1). These SNPs were described by Nie et al. (2005).

Polymorphisms, primers and restriction enzyme information

\begin{tabular}{|c|c|c|c|c|}
\hline Polymorphism & $\begin{array}{l}\text { Primer sequence } \\
\text { (forward/reverse) }\end{array}$ & $\mathrm{Ta}\left({ }^{\circ} \mathrm{C}\right)$ & Length (bp) & $\mathrm{RE}$ \\
\hline A213C exon 1 of Spot $14 \alpha$ (AY568628) & $\begin{array}{c}\text { CAGGAGGGAGCAGAGGGATAG/ } \\
\text { GGTCGGTCAGAACCTGCTGC }\end{array}$ & 60 & 419 & $B s a \mathrm{HI}$ \\
\hline A570C promoter of IGF1 (M74176) & $\begin{array}{l}\text { CATTGCGCAGGCTCTATCTG/ } \\
\text { TCAAGAGAAGCCCTTCAAGC }\end{array}$ & 57 & 813 & $\operatorname{HinfI}$ \\
\hline G645T exon 2 of IGFBP2 (U15086) & $\begin{array}{l}\text { AACAGGCATGAAGGAGATGG/ } \\
\text { CTCGCCAGCACATCAAAGT }\end{array}$ & 52 & 315 & BseGI \\
\hline A370G exon 2 of SST (X60191) & $\begin{array}{c}\text { CCTGTTTTCTCTCCCCTCAC/ } \\
\text { AGTCTTCGCCTCTCGTGGT }\end{array}$ & 55 & 330 & BsrBI \\
\hline 24 bp insertion promoter of PRL (FJ663023 or FJ434669) & $\begin{array}{c}\text { GGTGGGTGAAGAGACAAGGA/ } \\
\text { TGCTGAGTATGGCTGGATGT }\end{array}$ & 56 & 201 and/or 177 & - \\
\hline
\end{tabular}

Note: Ta - annealing temperature in ${ }^{\circ} \mathrm{C}$; Length - length of PCR products (bp); RE - restriction endonuclease

DNA amplification (PCR) of each individual broiler was performed according to the following conditions: the PCR was performed in a total volume of $25 \mu \mathrm{l}$ mixtures containing $1 \mu \mathrm{l}(200 \mathrm{ng})$ of genomic DNA, $12.5 \mu 1$ 2x PCR Mastermix (Promega, USA; Thermo Fisher Scientific, USA), $1 \mu$ l of appropriate oligonucleotide primer $(0.4 \mu \mathrm{M}$; Table 1$)$ and nuclease free water up to $25 \mu \mathrm{l}$ final volume. The PCR parameters were: $4 \mathrm{~min}$ at $95{ }^{\circ} \mathrm{C}$, followed by 35 cycles of $1 \mathrm{~min}$ at $95{ }^{\circ} \mathrm{C}, 1 \mathrm{~min}$ at annealing temperature (Table 1), $1 \mathrm{~min}$ at $72{ }^{\circ} \mathrm{C}$ and final extension of $4 \mathrm{~min}$ at $72{ }^{\circ} \mathrm{C}$. The PCR products were digested in a total volume of $20 \mu 1$ reaction containing $10 \mu \mathrm{l}$ of the PCR products, $10 \mathrm{U}$ of appropriate restriction enzyme (Table 1) according to manufacturers' (Promega and Thermo Fischer Scientific) recommendations, and nuclease-free water up to final volume. Restriction fragments were electrophoresed on 2\% agarose gels (Agarose, LE, Analytical Grade; Promega) with ethidium-bromide (10 $\mathrm{mg} / \mathrm{ml}$ stock concentration, $0.5 \mu \mathrm{g} / \mathrm{ml}$ final concentration; Promega), and individual PCR-RFLP fragment size in each samples were determined by FastRuler Low Range DNA Ladder (Thermo Scientific) under UV illumination. The $24 \mathrm{bp}$ insertion of PRL genotyping was done by loading PCR products straight on $3 \%$ agarose gel.

\section{Statistical analysis}

The Hardy-Weinberg Equilibrium (HWE) was tested by Chi-square analysis (SPSS 20.0 for Windows) for observed and expected genotype frequencies. HWE analyses for SST were not adaptable, since only one allele of the examined locus was present in the investigated populations. Genotypetrait associations were tested by independent samples t-tests or Mann-Whitney tests.

\section{RESULTS AND DISCUSSION}

The genotype and allele frequencies of Spot $14 \alpha$, IGF1, IGFBP2, SST and PRL are shown in Table 2. Chi-square test of HWE was not applicable for SST since only allele A was present in the population, whereas other genes were in HWE $(\mathrm{P}>0.05)$.

The A213C SNP in Spot 14 $\alpha$ results in aspartic (allele C) to glutamic (allele A) acid change. In broiler population only two of three genotypes were found in Spot 14a: AC and CC; whereas AA genotype was not found. A higher frequency of allele $\mathrm{C}$ was represented (Table 2). Allele A was identified by a 419 bp fragment, allele $\mathrm{C}$ was demonstrated by 319 and 100 bp long fragments. The Spot $14 \alpha$ genotype had no significant $(\mathrm{P}>0.05)$ effect on body weight or other measured traits in the investigating broiler population (Table 3). 
Genotype and allele frequencies in broilers

\begin{tabular}{|c|c|c|c|}
\hline Locus & Allele frequency & Genotype frequency & HWE Chi-square values \\
\hline A213C in Spot $14 \alpha$ & $\mathrm{A}=0.11 \mathrm{C}=0.89$ & $\mathrm{AA}=0.00 \quad \mathrm{AC}=0.23 \quad \mathrm{CC}=0.77$ & 0.675 \\
\hline $\mathrm{A} 570 \mathrm{C}$ in $I G F 1$ & $\mathrm{~A}=0.90 \mathrm{C}=0.10$ & $\mathrm{AA}=0.80 \mathrm{AC}=0.20 \quad \mathrm{CC}=0.00$ & 0.494 \\
\hline G645T in $I G F B P 2$ & $\mathrm{G}=0.93 \mathrm{~T}=0.07$ & $\mathrm{GG}=0.85 \mathrm{GT}=0.15 \mathrm{TT}=0.00$ & 0.263 \\
\hline A370G in $S S T$ & $\mathrm{~A}=1.00 \mathrm{G}=0.00$ & $\mathrm{AA}=1.00 \mathrm{AG}=0.00 \mathrm{GG}=0.00$ & n.a. \\
\hline 24 bp indel in $P R L$ & $\mathrm{I}=0.22 \quad \mathrm{D}=0.78$ & $\mathrm{DD}=0.60 \quad \mathrm{ID}=0.35 \quad \mathrm{II}=0.05$ & 0.001 \\
\hline
\end{tabular}

Genotype and body composition trait associations in broilers

\begin{tabular}{lcccccc}
\hline \multicolumn{2}{c}{ Genotype } & & BW $(\mathrm{g})$ & $\mathrm{CW}(\mathrm{g})$ & BMWS $(\mathrm{g})$ & $\mathrm{BMW}(\mathrm{g})$ \\
\hline \multirow{2}{*}{ Spot $14 \alpha$} & AC & $2059.01 \pm 238.46$ & $1541.57 \pm 177.13$ & $506.67 \pm 88.98$ & $452.67 \pm 90.44$ & $470.56 \pm 55.69$ \\
& CC & $2010.30 \pm 206.11$ & $1520.60 \pm 156.34$ & $507.804 \pm 73.08$ & $469.77 \pm 80.97$ & $459.31 \pm 59.24$ \\
\hline \multirow{2}{*}{ IGFBP2 } & GG & $2025.53 \pm 216.33$ & $1530.35 \pm 161.18$ & $507.03 \pm 77.19$ & $459.31 \pm 82.78$ & $462.56 \pm 59.53$ \\
& GT & $1991.17 \pm 176.05$ & $1492.00 \pm 140.89$ & $504.83 \pm 67.31$ & $476.50 \pm 77.57$ & $459.00 \pm 38.25$ \\
\hline \multirow{3}{*}{$P R L$} & DD & $2067.54 \pm 198.70^{\mathrm{a}}$ & $1562.67 \pm 148.15^{\mathrm{a}}$ & $524.50 \pm 70.33$ & $476.55 \pm 75.72$ & $479.08 \pm 49.67^{\mathrm{a}}$ \\
& ID & $1978.86 \pm 207.48$ & $1486.00 \pm 159.87$ & $482.64 \pm 81.04$ & $449.50 \pm 91.69$ & $441.79 \pm 59.55^{\mathrm{b}}$ \\
& II & $1745.00 \pm 91.92^{\mathrm{b}}$ & $1338.00 \pm 29.00^{\mathrm{b}}$ & $461.50 \pm 19.09$ & $417.00 \pm 12.73$ & $399.00 \pm 28.28^{\mathrm{b}}$ \\
\hline
\end{tabular}

Note: BW - body weight at $38^{\text {th }}$ day; CW - carcass weight; BMWS - breast muscle weight with skin; BMW - breast muscle weight without skin; LW - leg weight with skin and bone

Chicken with genotype AC had heavier body weight, nevertheless the effect of allele A was not significant $(\mathrm{P}>0.05)$. Cao et al. (2007) found in an F2 broiler-layer cross significant association between the polymorphism and body weight of 5 to 12-week-old chickens, individuals with CC genotype had significantly $(\mathrm{P}<0.05)$ higher body and carcass weight than with other genotypes. The SNP had no effect on the measured body composition traits. In an F2 population of White Recessive Rock and Xinghua breeds, SNPs located in the 5' flanking region of this gene were associated with body weight at younger ages [hatch and 28-day weight, Hirwa et al. (2010)]. Based on these contradictory results, a non-direct effect of A213C SNP was proposed, suggesting that the actual causative mutation was nearly linked to the investigated SNP, and was in inverse linkage in the different populations. Before using this SNP in marker assisted selection programs, attention must be given to survey the actual direction of the allele substitution effect in the particular breed or line.

Two of three $I G F 1$ genotypes (A570 C SNP) were found $(\mathrm{AA}, \mathrm{AC})$ in the investigated broiler population; the $\mathrm{CC}$ genotype was not found (Table 2). Allele A was characterized by three fragments of sizes 378 , 244, and $191 \mathrm{bp}$, whereas allele C was represented by 622 and 191 bp long fragments. Similar to other authors, allele A frequency was higher in the broiler population. There was no $I G F 1$ genotype-phenotype comparison in this study, because a different set $(n=40)$ of the ROSS 308 broiler population without production trait measurements were used to determine $I G F 1$ genotype frequencies. However, in several studies the role of $I G F I$ in growth and breast muscle weight was confirmed (Lei et al. 2005, Zhou et al. 2005, Kadlec et al. 2011, Sato et al. 2012).

Two of three genotypes were observed in IGFBP2 (GG, GT), the TT genotype was not found (Table 2).
Allele $\mathrm{G}$ was demonstrated by 198 and 117 bp long products, allele $\mathrm{T}$ was represented by a $315 \mathrm{bp}$ long fragment. In the examined broiler population, in which two genotypes in IGFBP2 were found, homozygous $\mathrm{G}$ birds had heavier body and carcass weight, than chickens with heterozygous genotype (Table 3), but the difference was not significant $(\mathrm{P}>0.05)$. Association between $I G F B P 2$ and some growth traits (Nie et al. 2005, Li et al. 2006), furthermore carcass and body composition traits ( $\mathrm{Li}$ et al. 2006, Zhao et al. 2015) were reported in several chicken populations. The G645T is non-synonymous and significant differences $\quad(\mathrm{P}<0.05)$ were found between polymorphism and body weight in F2 designed population was made up of reciprocal cross between White Recessive Rock and Xinghua chickens (Lei et al. 2005).

Allele A at A370G locus in SST was fixed in the examined broiler population (Table 2). The fixed genotype was characterized by the uncut $330 \mathrm{bp}$ long PCR product. This SNP was described by Nie et al. (2005), when Leghorn, White Recessive Rock, Taihe silkies and Xinghua breed were contrasted. Tempfli et al. (2015) also reported the fixed AA genotype in Hungarian Yellow chicken. Other reports have not been presented about genotype-trait association of this polymorphism. Therefore, further investigations involving other breeds are necessary to assess the effect and frequency of the polymorphism.

In the broiler population all the three genotypes (DD, ID, II) were found in PRL. Allele I was identified as a $201 \mathrm{bp}$ long fragment, whereas allele D was characterized by a $177 \mathrm{bp}$ long product. In the examined broiler population there was significant difference $(\mathrm{P}<0.05)$ in body, carcass, and leg weight (Table 3). All measured traits were greater in homozygous D chicken, compared to heterozygous animals. However, genotype differences regarding 
body and carcass weight were not significant ( $P>0.05$ ). Jiang et al. (2005) reported that the insertion frequency greatly differed among breeds, and was commonly higher in layer populations. Based on the highly polymorphic $P R L$ promoter, also significant $(\mathrm{P}<0.05) P R L$ haplogroup associations were described in White Leghorn lines with body weight of chickens at sexual maturity and at 16 and 64 weeks of age (Bhattacharya et al. 2011).

\section{CONCLUSION}

There were no significant differences $(\mathrm{P}>0.05)$ between measured production traits of Spot $14 \alpha$ and IGFBP2 genotypes. However, some authors previously found differences among the genotypes and growth traits. The SST was fixed in the investigated population. In $P R L$ there was significant difference $(\mathrm{P}<0.05)$ in some important production traits (live and carcass weight). Because of the low samples number, involvement of more samples is planned in further experiments. The analyzed polymorphic markers provide potentially useful information for breed improvement.

\section{AKNOWLEDGEMENTS}

The work is supported by the EFOP-3.6.3-VEKOP16-2007-00008 project. The project is co-financed by the European Union and the European Social Fund.

\section{REFERENCES}

Angelier, F.-Chastel, O. (2009): Stress, prolactin and parental investment in birds: A review. Gen. Comp. Endocrinol. 163: $142-148$.

Bhattacharya, T. K.-Chatterjee, R. N.-Sharma, R. P.-Niranjan, M.Rajkumar, U.-Reddy, B. L. N. (2011): Polymorphism in the prolactin promoter and its association with growth traits in chickens. Biochem. Genet. 49: 385-394.

Cao, Z. P.-Wang, S. Z.-Wang, Q. G.-Wang, Y. X.-Li, H. (2007) Association of Spot $14 \alpha$ Gene Polymorphisms with Body Weight in the Chicken. Poult. Sci. 86: 1873-1880.

d'A.Hirwa, C.-Yan, W.-Wallace, P.-Nie, Q.-Luo, C.-Li, H.-Shen, X.-Sun, L.-Tang, J.-Li, W.-Zhu, X.-Yang, G.-Zhang, X. (2010): Effects of the thyroid hormone responsive spot $14 \alpha$ gene on chicken growth and fat traits. Poult. Sci. 89: 19811991.

Jiang, R. S.-Xu, G. Y.-Zhang, X. Q.-Yang, N. (2005): Association of polymorphisms for prolactin and prolactin receptor genes with broody traits in chickens. Poult. Sci. 84. 6: 839-845.

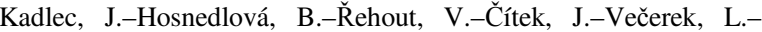
Hanusová, L. (2011): Insulin-like growth factor-I gene polymorphism and its association with growth and slaughter characteristics in broiler chickens. J. Agrobiol. 28. 2: 157-163.

Kita, K.-Nagao, K.-Taneda, N.-Inagaki, Y.-Hirano, K.-Shibata, T.-Aman Yaman, M.-Conlon, M. A.-Okumura, J. (2002): Insulin-Like Growth Factor Binding Protein-2 Gene Expression Can Be Regulated by Diet Manipulation in Several Tissues of Young Chickens. J. Nutr. 132: 145-151.

Lei, M. M.-Nie, Q. H.-Peng, X.-Zhang, D. X.-Zhang, X. Q (2005): Single nucleotide polymorphisms of the chicken insulin-like factor binding protein 2 gene associated with chicken growth and carcass traits. Poult. Sci. 84: 1191-1198.

Li, Z. H.-Li, H.-Zhang, H.-Wang, S. Z.-Wang, Q. G.-Wang, Y. X. (2006): Identification of a single nucleotide polymorphism of the insulin-like growth factor binding protein 2 gene and its association with growth and body composition traits in the chicken. J. Anim. Sci. 84: 2902-2906.
Nie, Q.-Lei, M.-Ouyang, J.-Zeng, H.-Yang, G.-Zhang, X. (2005): Identification and characterization of single nucleotide polymorphisms in 12 chicken growth-correlated genes by denaturing high performance liquid chromatography. Genet. Sel. Evol. 37: 339-360.

Sato, S.-Ohtake, T.-Uemoto, Y.-Okumura, Y.-Kobayashi, E. (2012): Polymorphism of insulin-like growth factor 1 gene is associated with breast muscle yields in chickens. Anim. Sci. 83: $1-6$.

Silha, J. V.-Murphy, L. J. (2005): Insulin-like growth factor binding proteins in development. Advance in Experimental Medicine and Biology. 567: 55-89.

Tempfli, K.-Konrád, Sz.-Kovácsné Gaál, K.-Pongrácz, L.-Bali Papp, Á. (2015): Prolactin, dopamine receptor D1 and Spot $14 \alpha$ polymorphisms affect production traits of Hungarian Yellow hens. Livest. Sci. 174: 26-30.

Wang, X.-Carre, W.-Zhou, H.-Lamont, S. J.-Cogburn, L. A. (2004): Duplicated Spot 14 genes in the chicken: Characterization and identification of polymorphisms associated with abdominal fat traits. Genetics. 332: 79-88.

Zhao, X. H.-Li, M. Y.-Xu, S. S.-Liu, G. J. (2015): Single Nucleotide Polymorphisms in IGFBP-2 Gene and Their Associations with Body Weight Traits on Jinghai Yellow Chicken. Braz. J. Poult. Sci. 17. 4: 497-502.

Zhou, H.-Mitchell, A. D.-McMurtry, J. P.-Ashwell, C. M.Lamont, S. J. (2005): Insulin-Like Growth Factor-I Gene Polymorphism Associations with Growth, Body Composition, Skeleton Integrity, and Metabolic Traits in Chickens. Poult. Sci. 84: 212-219. 